\title{
GLOBAL PRODUCTION AND DECAY OF RADIOCARBON
}

\author{
PAUL E DAMON \\ Laboratory of Isotope Geochemistry, Department of Geosciences \\ University of Arizona, Tucson, Arizona 85711 \\ and \\ ROBERT E STERNBERG \\ Geology Department, Franklin and Marshall College \\ Lancaster, Pennsylvania 17604
}

\begin{abstract}
The production rate of ${ }^{14} \mathrm{C}$ during the Holocene averaged $2.4 \pm 0.2$ atoms ${ }^{14} \mathrm{C} / \mathrm{cm}_{\mathrm{e}}^{2} \mathrm{sec}$. Neutrons produced by galactic cosmic rays account for $90 \%$ of the ${ }^{14} \mathrm{C}$ production with the remaining $10 \%$ resulting from neutrons produced by protons from solar flares. Production and decay of ${ }^{94} \mathrm{C}$ can be reconciled by including ${ }^{14} \mathrm{C}$ permanently or temporarily stored in sediments. Sedimentary reservoirs contain ca $30 \%$ of all terrestrial ${ }^{14} \mathrm{C}$. The lagoons, bays, marshes and deltas of the coastal wetlands alone account for $12 \%$ of the ${ }^{14} \mathrm{C}$ inventory. The capacity of the coastal wetlands to store carbon has become the subject of renewed interest.
\end{abstract}

\section{PRODUCTION OF RADIOCARBON}

${ }^{14} \mathrm{C}$ is produced by the secondary neutron flux resulting from spallation of atmospheric isotopes. These neutrons are almost quantitatively involved in interaction with ${ }^{14} \mathrm{~N}$ to produce ${ }^{14} \mathrm{C}$ plus tritium in the reactions ${ }^{14} \mathrm{~N}(\mathrm{n}, \mathrm{p}){ }^{14} \mathrm{C}$ and ${ }^{14} \mathrm{~N}(\mathrm{n}, \mathrm{T}){ }^{12} \mathrm{C}$. There were seven different calculations of the production rate of ${ }^{14} \mathrm{C}$ during the decade $1970-1980$. The estimated production rates for the 1965 solar minimum and 1969 solar maximum are shown in Table 1. Six of the calculations are in good agreement and average $2.47 \pm 0.19{ }^{14} \mathrm{C}$ atoms $/ \mathrm{s} \mathrm{cm}$ e for solar minimum and $2.02 \pm 0.13{ }^{14} \mathrm{C}$ atoms $/ \mathrm{s} \mathrm{cm}_{\mathrm{e}}^{2}$ for solar maximum. Surprisingly, the lowest estimate by O'Brien (1979) is commonly used in modeling ${ }^{4} \mathrm{C}$ in the carbon cycle (eg, Stuiver \& Quay, 1980 ) because it agrees with the decay rate as estimated from ${ }^{14} \mathrm{C}$ inventories (eg, Siegenthaler, 1985). Siegenthaler calculated a decay rate of $1.73 \mathrm{dps} \mathrm{\textrm {cm } _ { \mathrm { e } } ^ { - 2 }}$. We obtained a higher value, $2.01 \mathrm{dps} \mathrm{cm}_{\mathrm{e}}^{-2}$, and suggested that the global decay rate was compatible with the higher estimates of the production rate (Damon, Sternberg \& Radnell, 1982). The difference lies in the amount of ${ }^{14} \mathrm{C}$ estimated to be in the sedimentary reservoir. According to Siegenthaler, Heimann and Oeschger (1980), "sedimentation is neglected as well as other minor fluxes, because it removes only ca $0.5 \times 10^{-5}$ parts of the total oceanic amount of carbon $\left(\right.$ or ${ }^{14} \mathrm{C}$ ) per year." However, ${ }^{14} \mathrm{C}$ accumulates in sediments during its mean life of 8270 years and it can be shown that sediments contain a significant part of the total global inventory.

Past changes in atmospheric ${ }^{14} \mathrm{C}$ concentrations $\left({ }^{14} \mathrm{C} / \mathrm{C}\right)$ are evaluated by measuring the carbon isotopic content of dendrochronologically dated tree rings. The ${ }^{14} \mathrm{C}$ concentration is corrected for radioactive decay and isotopic fractionation and compared with mid-19th century wood. The per mil (\%o) difference is referred to as $\Delta^{14} \mathrm{C}$. The trend of $\Delta^{14} \mathrm{C}$ excluding short-term fluctuations can be approximated by a sinusoidal curve with a period of ca 11,000 years back to 6500 BC (Bruns et al, 1983; Damon \& Linick, 1986) but may deviate from a sinusoidal curve prior to that time (Kromer et al, 1986). Since the Twelfth Nobel Symposium held in Uppsala, Sweden in August 1969, this 
long-term trend of $\Delta^{14} \mathrm{C}$ has been attributed to secular variation of the strength of the geomagnetic dipole moment resulting in changes in the rate of production of ${ }^{14} \mathrm{C}$ (Olsson, 1970). ${ }^{14} \mathrm{C}$ integrates changes in production rate resulting from changes in the dipole moment on a global basis whereas individual archaeomagnetic measurements are strongly affected by the nondipole components. Generally, it appears that the dipole moment field strength was lower than at present prior to the 5th century $\mathrm{BC}$ and higher afterwards (McElhinny \& Senanyake, 1982). Thus, the ${ }^{14} \mathrm{C}$ production rate, $\mathrm{Q}(\mathrm{t})$, would have been higher prior to the 5th century BC and lower more recently. The global ${ }^{14} \mathrm{C}$ inventory can be calculated from the following relationship (Sternberg \& Damon, 1979; Damon, Sternberg \& Radnell, 1982):

$$
I=-\lambda_{\infty} \int^{0} Q(t) e^{-\lambda t} d t
$$

where I (inventory) is the global decay rate, $\lambda$ is the ${ }^{14} \mathrm{C}$ decay constant, and $\mathrm{Q}(\mathrm{t})$ is the production rate as a function of time, $\mathrm{t}$. $\mathrm{Q}(\mathrm{t})$ is proportional to $\mathrm{M}(\mathrm{t})^{-\alpha}$, where $\alpha=0.52$ and $\mathrm{M}(\mathrm{t})$ is the time-varying dipole field strength. The function $M(t)^{-\alpha}$ is asymmetric. A decrease in the dipole moment has a much greater effect than a corresponding increase (Sternberg \& Damon, 1979, see Fig 12). Thus, fortuitously, the higher earlier production rates offset the more recent lower production rates and the calculated inventory I is not significantly different than the average production rate by galactic cosmic rays during recent solar cycles which is ca $2.2{ }^{14} \mathrm{C}$ aps cme $\mathrm{cm}_{\mathrm{e}}^{-2}$ or 132 apm $\mathrm{cm}_{\mathrm{e}}^{-2}$ (Table 1).

TABLE 1

Comparison of ${ }^{14} \mathrm{C}$ production calculations (atoms $/ \mathrm{sec} \mathrm{cm}_{\mathrm{e}}^{2}$ ).

\begin{tabular}{lcccccccc}
\hline Year & $\begin{array}{c}\text { Solar } \\
\text { max+min }\end{array}$ & $\begin{array}{c}\text { Merker } \\
(1970)\end{array}$ & $\begin{array}{c}\text { L\&R* } \\
(1970)\end{array}$ & $\begin{array}{c}\text { Light } \\
\text { et al } \\
(1973)\end{array}$ & $\begin{array}{c}\text { Povinec } \\
(1977)\end{array}$ & $\begin{array}{c}\text { O'Brien } \\
(1979)\end{array}$ & $\begin{array}{c}\text { K\&M* } \\
(1980)\end{array}$ & $\begin{array}{c}\text { C\&L* } \\
(1980)\end{array}$ \\
\hline 1965 & 15.1 & 2.15 & 2.40 & 2.42 & 2.6 & 1.91 & 2.58 & 2.66 \\
1969 & 105.6 & 1.86 & 2.18 & 1.93 & 2.1 & 1.60 & 1.93 & 2.12 \\
\hline
\end{tabular}

${ }^{*}$ L\&R: Lingenfelter and Ramaty

K\&M: Korff and Mendell

C\&L: Castagnoli and Lal

\section{DECAY OF RADIOCARBON}

There is general agreement concerning the ${ }^{14} \mathrm{C}$ inventory of preanthropogenic ambient reservoirs, ie, reservoirs with transfer times that are much less than the half-life of ${ }^{14} \mathrm{C}$ (5730 years). The inventory for ambient reservoirs is given in Table 2. Note that the summed inventory is ca $20 \%$ less than the current average production rate. If the model from which I in equation 1 was estimated is correct. the difference must lie either in the calculation of production rates or in a missing component of the inventory. The missing component is the controversial sedimentary reservoir.

Much attention has been given in recent years to storage of carbon in sediments because of the need to account for the "missing" anthropogenic carbon resulting from the combustion of fossil fuels and agricultural practices such as the clearing of forests. I have taken advantage of this flourishing lit- 
TABLE 2

${ }^{14} \mathrm{C}$ inventory of pre-anthropogenic ambient reservoirs

\begin{tabular}{|c|c|c|c|c|}
\hline Ref* & Reservoir & $\begin{array}{l}\text { Cin reservoir } \\
\quad\left(\mathrm{g} / \mathrm{cm}_{\mathrm{e}}^{2}\right)\end{array}$ & $\begin{array}{c}{ }^{14} \mathrm{C} \text { activity } \\
\text { of reservoir } \\
(\mathrm{dpm} / \mathrm{gC})\end{array}$ & $\begin{array}{l}\text { Reservoir } \\
\text { decay rate } \\
\left(\mathrm{dpm} / \mathrm{cm}_{\mathrm{e}}^{2}\right)\end{array}$ \\
\hline 1 & Atmosphere & $0.116 \pm 0.002$ & $14.1 \pm 0.5$ & $1.64 \pm 0.06$ \\
\hline 2 & $\begin{array}{l}\text { Terrestrial biosphere } \\
\text { (rapid, vascular, heterotroph } \\
\text { and litter) }\end{array}$ & $0.172 \pm 0.020$ & $13.6 \pm 0.6$ & $2.34 \pm 0.29$ \\
\hline 2 & Soil humus & $0.393 \pm 0.029$ & $13.2 \pm 0.6$ & $5.19 \pm 0.45$ \\
\hline 2 & $\begin{array}{l}\text { Hydrosphere, mixed layer } \\
\text { of ocean }(0-75 \mathrm{~m})\end{array}$ & $0.122 \pm 0.005$ & $13.4 \pm 0.5$ & $1.63 \pm 0.09$ \\
\hline 2 & $\begin{array}{l}\text { Hydrosphere, intermediate } \\
\text { and deep ocean }\end{array}$ & $7.420 \pm 0.030$ & $11.8 \pm 0.5$ & $87.56 \pm 3.73$ \\
\hline 2 & $\begin{array}{l}\text { Saprosphere (total organic } \\
\text { matter in oceans) }\end{array}$ & $0.274 \pm 0.078$ & $13.3 \pm 0.5$ & $3.64 \pm 1.05$ \\
\hline \multirow[t]{2}{*}{3} & Fresh surface water & $0.0002 \pm 0.001$ & $13.0 \pm 0.6$ & $0.03 \pm 0.02$ \\
\hline & & $\Sigma=8.50 \pm 0.14$ & & $\Sigma=102 \pm 4$ \\
\hline
\end{tabular}

*1. Oeschger et al (1975), $280 \pm 5$ ppm; 2. Olson et al (1985); 3. Kemp (1979)

erature to estimate the ${ }^{14} \mathrm{C}$ inventory of sediments (Table 3 ). This estimate differs from our earlier estimates in the addition of organic matter in the coastal wetlands which are now considered to be as important as the marine carbonate reservoir. Much of the carbon storage in this reservoir is in the form of macrophyte (large marine plants such as eel grass, kelp and intertidal marsh grasses). A higher fraction of macrophyte than phytoplankton escapes oxidation and is buried in marsh and other coastal sediments (Baes, Björkstrom \& Mulholland, 1985) or transported to the shelf area (Walsh, 1984). Carbon that is rapidly cycled is not included in the inventory. Table 3 only includes carbon that is stored for a sufficiently long time to allow most of the ${ }^{14} \mathrm{C}$ to decay.

TABLE 3

${ }^{14} \mathrm{C}$ inventory in buried sediment (long-term storage)

\begin{tabular}{llccc}
\hline Ref* & Reservoir & $\begin{array}{c}\text { Caccumulated during } \\
\text { mean life of }{ }^{14} \mathrm{C} \\
\left(\mathrm{g} / \mathrm{cm}_{\mathrm{e}}^{2}\right)\end{array}$ & $\begin{array}{c}{ }^{14} \mathrm{C} \text { activity } \\
\text { of C flux } \\
(\mathrm{dpm} / \mathrm{gC})\end{array}$ & $\begin{array}{c}\text { Reservoir } \\
\text { decay rate } \\
\left(\mathrm{dpm} / \mathrm{cm}_{\mathrm{e}}^{2}\right)\end{array}$ \\
\hline 1 & $\begin{array}{l}\text { Continental shelves } \\
\text { (carbonate) }\end{array}$ & $0.033 \pm 0.016$ & $13.4 \pm 0.6$ & $0.44 \pm 0.21$ \\
1 & $\begin{array}{l}\text { Continental slopes } \\
\text { and deep ocean (carbonate) }\end{array}$ & $0.853 \pm 0.178$ & $13.4 \pm 0.6$ & $11.43 \pm 2.86$ \\
2 & $\begin{array}{l}\text { Continental shelves } \\
\text { (organic) }\end{array}$ & $0.178 \pm 0.089$ & $13.4 \pm 0.6$ & $2.38 \pm 1.20$ \\
3 & $\begin{array}{l}\text { Continental slopes } \\
\text { and deep ocean (organic) }\end{array}$ & $0.026 \pm 0.013$ & $13.4 \pm 0.6$ & $0.35 \pm 0.18$ \\
\hline $\begin{array}{l}\text { Coastal wetlands } \\
\text { (lagoons, marshes, }\end{array}$ & $1.135 \pm 0.378$ & $13.2 \pm 0.6$ & $14.98 \pm 5.95$ \\
$\begin{array}{l}\text { bays and deltas) } \\
\text { Freshwater lakes } \\
\text { and wetlands }\end{array}$ & $0.24 \pm 0.03$ & $13.4 \pm 0.6$ & $3.22 \pm 0.42$ \\
\hline
\end{tabular}

*1. Hay (1985); 2. Berner (1982); 3. Baes et al (1985); 4. Kemp (1979) 


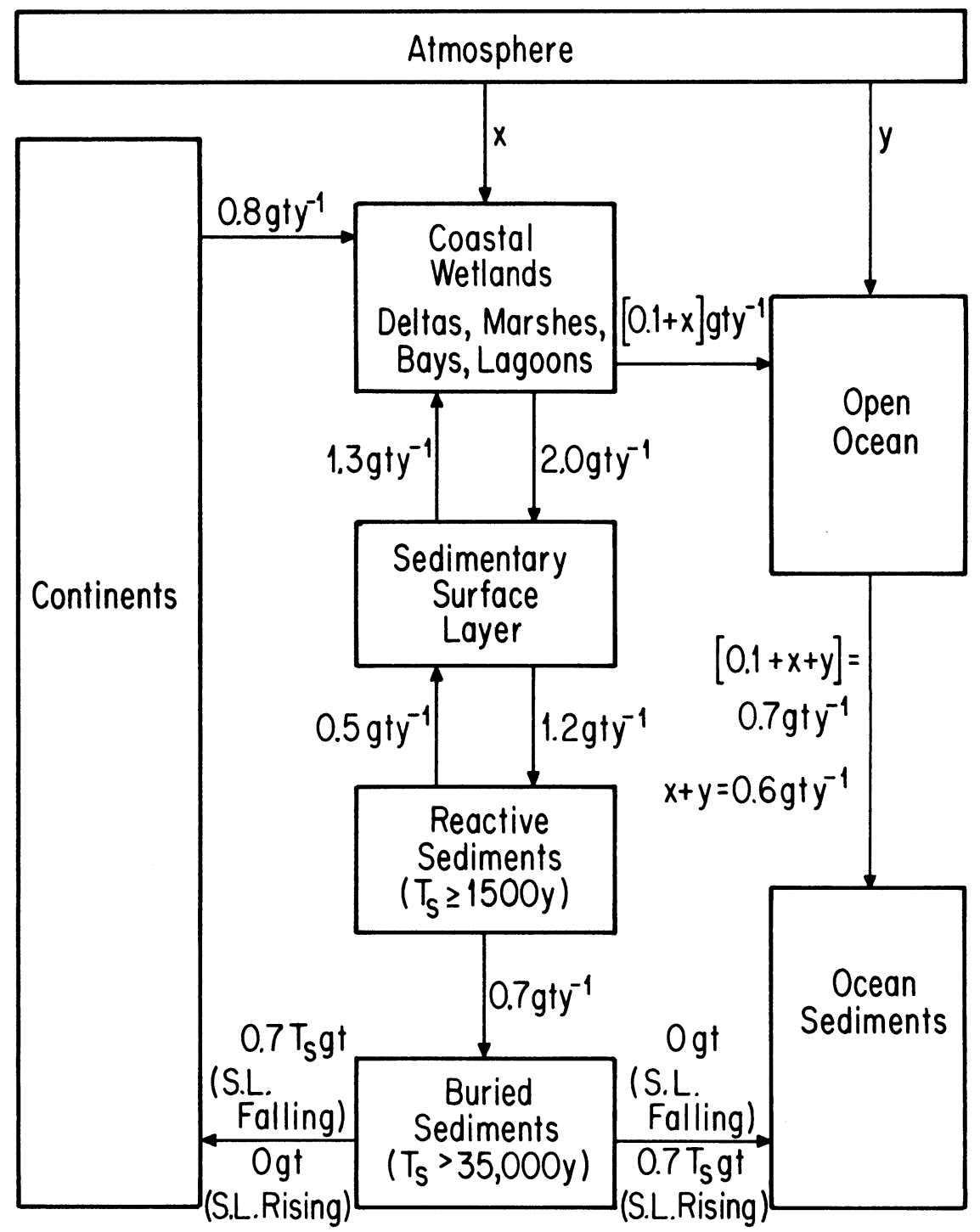

Fig 1. Marine carbon fluxes. The fluvial input of carbon is augmented by photosynthesis. Ca $40 \%$ of the flux to the surface sediments is rapidly recycled with negligible decay of ${ }^{14} \mathrm{C}$. $\mathrm{Ca} 25 \%$ is recycled from the reactive sediments after appreciable decay of ${ }^{14} \mathrm{C}$ and ca $35 \%$ is transferred to the buried sediments where all ${ }^{14} \mathrm{C}$ decays. Falling sea level may return coastal sediments to land whereas rising sea level shifts the coastal sediments to the open ocean. Part of the coastal wetland carbon flux is transferred to the open oceans where further augmentation by photosynthesis takes place. Carbon in the open ocean goes through a similar sequence of stages, not shown here, before a similar amount is permanently stored long enough for all ${ }^{14} \mathrm{C}$ to decay. 
The amount of carbon stored temporarily and returned to the ambient reservoirs before all ${ }^{14} \mathrm{C}$ has decayed is even more difficult to evaluate. From Table 3 , (column 3 ) ca $0.7 \mathrm{~g} \mathrm{t} \mathrm{y}^{-1}$ is stored in the wetlands and approximately the same amount is stored in ocean sediments long enough for ${ }^{14} \mathrm{C}$ to decay. The amount of carbon entering the oceans is ca $0.8 \mathrm{~g} \mathrm{t} \mathrm{y}^{-1}$ (Baes, Björkstrom $\&$ Mulholland, 1985). Figure 1 shows some features of the fluvial flux, ocean, atmosphere and sediment cycle. The fluvial flux enters the wetlands carbon cycle, depositing a large amount on the sedimentary surface annually. Part of this is rapidly returned to the aqueous phase with negligible ${ }^{14} \mathrm{C}$ decay. Another part is stored temporarily in reactive sediments but long enough for significant ${ }^{14} \mathrm{C}$ decay and the remainder is deposited permanently, ie, long enough for all ${ }^{14} \mathrm{C}$ to decay. $\mathrm{CO}_{2}$ also enters the ocean through photosynthesis. Part of the carbon passes into the open ocean where photosynthesis fixes more carbon and sediments accumulate on the sea floor. An attempt at balancing the cycle is given in Figure 1. Falling sea level yields sediments to land for recycling and rising sea level transfers buried sediment to the open ocean.

TABLE 4

${ }^{14} \mathrm{C}$ inventory of reactive sediments

\begin{tabular}{|c|c|c|c|c|}
\hline Ref* $^{*}$ & Reservoir & $\begin{array}{l}\text { Cin reservoir } \\
\left(\mathrm{g} / \mathrm{cm}_{\mathrm{e}}^{2}\right)\end{array}$ & $\begin{array}{c}{ }^{14} \mathrm{C} \text { activity } \\
\text { of reservoir } \\
\text { (dpm/gC) }\end{array}$ & $\begin{array}{l}\text { Reservoir } \\
\text { decay rate } \\
\left(\mathrm{dpm} / \mathrm{cm}_{\mathrm{e}}^{2}\right)\end{array}$ \\
\hline 1 & $\begin{array}{l}\text { Continental paleosols, } \\
\text { peat and sediment }\end{array}$ & $0.100 \pm 0.030$ & $10.7 \pm 0.8$ & $1.07 \pm 0.33$ \\
\hline 1 & Marine organic & $0.127 \pm 0.040$ & $4.9 \pm 0.8$ & $1.32 \pm 0.46$ \\
\hline 2 & Marine carbonate & $0.490 \pm 0.160$ & $5.5 \pm 0.8$ & $2.74 \pm 0.96$ \\
\hline \multirow[t]{2}{*}{$2,3,4$} & Coastal wetlands & $0.196 \pm 0.065$ & $11.0 \pm 0.8$ & $2.16 \pm 0.73$ \\
\hline & & $\Sigma=0.913$ & & $\Sigma=8.38 \pm 1.3$ \\
\hline
\end{tabular}

*1. Sundquist (1985); 2. Baes et al (1985); 3. Wollast and Billen (1981); 4. Mulholland (1981)

TABLE 5

Distribution of ${ }^{14} \mathrm{C}$ in terrestrial nature

\begin{tabular}{lrr}
\hline \multicolumn{1}{c}{ Reservoir } & $\begin{array}{r}\text { Decay rate } \\
\left(\mathrm{dpm} / \mathrm{cm}_{\mathrm{e}}^{2}\right)\end{array}$ & $\begin{array}{r}\text { Relative } \\
\text { amount } \\
(\%)\end{array}$ \\
\hline Hydrosphere (mixed, intermediate and deep ocean) & 89.2 & 62.4 \\
All other ambient reservoirs & 12.8 & 9.0 \\
Coastal wetlands (lagoons, bays, marshes and deltas) & 15.0 & 10.4 \\
Reactive sediments & 8.4 & 5.8 \\
Carbonate in marine sediments & 11.9 & 8.2 \\
All other sediments & 6.0 & 4.2 \\
& & 100.0 \\
\hline
\end{tabular}

As mentioned above, the reactive sediments were not included in Table 3. An estimate is given in Table 4. Addition of this component increases the sedimentary ${ }^{14} \mathrm{C}$ storage by $25 \%$.

Table 5 summarizes the distribution of ${ }^{14} \mathrm{C}$ in terrestrial nature. The marine hydrosphere is the largest reservoir, including $62.4 \%$ of all ${ }^{14} \mathrm{C}$. All other 
ambient reservoirs include an additional $9.0 \%$, leaving $28.6 \%$ of the total in the sedimentary reservoirs. The sum is not significantly higher than the estimated average production rate by galactic cosmic rays. Nevertheless, solar flares also produce a significant amount of ${ }^{14} \mathrm{C}$ (Lingenfelter \& Ramaty, 1970; Damon, Cheng \& Linick, 1989) on the order of $10 \%$ of the galactic component. Thus, a total ${ }^{14} \mathrm{C}$ production rate of $143 \mathrm{dpm} / \mathrm{cm}_{\mathrm{e}}^{2}$ (Table 5) would not be unreasonable. If this is added to the galactic component, a total ${ }^{14} \mathrm{C}$ production rate of 2.4 aps $\mathrm{cm}_{\mathrm{e}}^{-2}$ is obtained.

\section{CONCLUSIONS}

The following conclusions seem to be warranted by the available data:

1) The average rate of ${ }^{14} \mathrm{C}$ production during recent sunspot cycles is $2.4 \pm 0.2{ }^{14} \mathrm{C}$ atoms $/ \mathrm{cm}_{\mathrm{e}}^{2}$ sec. Production rates are $90 \%$ by galactic cosmic rays and ca $10 \%$ by solar flare protons. This is also close to the average production rate during the Holocene calculated from equation 1.

2) This rate of production can be reconciled with the inventory of ${ }^{14} \mathrm{C}$ decay in terrestrial reservoirs if ${ }^{14} \mathrm{C}$ stored permanently or temporarily in buried sediments is taken into consideration. Reconciliation is required because atmospheric ${ }^{14} \mathrm{C}$ has not deviated from steady state by more than \pm $5 \%$ during the last 14,000 years (Damon \& Sonett, 1989). The total inventory is $2.38 \pm 0.13{ }^{14} \mathrm{C}$ atoms $/ \mathrm{cm}_{\mathrm{e}}^{2}$ sec.

3) Recent work has demonstrated that the lagoons, bays, marshes and deltas of the coastal wetlands constitute a ${ }^{14} \mathrm{C}$ reservoir approximately equal in magnitude to the ${ }^{14} \mathrm{C}$ stored in the sediments of the continental shelves, slopes and deep ocean. Ca $28.6 \%$ of terrestrial ${ }^{14} \mathrm{C}$ is stored in sedimentary reservoirs, $62.4 \%$ is present in the marine hydrosphere and $9 \%$ is stored in all other reservoirs. Future work should include a re-evaluation of the last reservoir in Table 3. Alexander Wilson of this laboratory has suggested that the evaluation by Kemp (1979) does not adequately account for the significant storage of carbon tundra wetlands.

\section{ACKNOWLEDGMENTS}

This work was supported by NSF Grants EAR-85-12761 and ATM8607164 and the State of Arizona.

\section{REFERENCES}

Baes, CF, Jr, Björkstrom, A and Mulholland, P J, 1985, Uptake of carbon dioxide by the oceans, in Trabalka, J R, ed, Atmospheric carbon dioxide and the global carbon cycle: US Dept Energy Rept DOE/ER-0239, p 81-112.

Berner, R A,1982, Burial of organic carbon and pyrite sulfur in the modern oceans: Its geochemical and environmental significance: Am Jour Sci, v 282, p 451-473.

Bruns, M, Rhein, M, Linick, T W and Suess, H E, 1983, The atmospheric ${ }^{14} \mathrm{C}$ level in the 7 th millennium BC, in Mook, W G and Waterbolk, H T, eds, ${ }^{14} \mathrm{C}$ and archaeology: Strasbourg, PACT, v 8, p 511-516.

Castagnoli, G and Lal, D, 1980, Solar modulation effects in terrestrial production of carbon-14, in Stuiver, $\mathrm{M}$ and $\mathrm{Kra}, \mathrm{R} \mathrm{S}$, eds, Internatl ${ }^{14} \mathrm{C}$ conf, 10th, Proc: Radiocarbon, v 22, no. 2, p 133-158.

Damon, P E, Cheng, S and Linick, T W, 1989, Fine and hyperfine structure in the spectrum of secular variations of atmospheric ${ }^{14} \mathrm{C}$ : Radiocarbon, this issue.

Damon, P E and Linick, T W, 1986, Geomagnetic-heliomagnetic modulation of atmospheric radiocarbon production, in Stuiver, $\mathrm{M}$ and $\mathrm{Kra}, \mathrm{R} \mathrm{S}$, eds, Internatl ${ }^{14} \mathrm{C}$ conf, 12 th, Proc: Radiocarbon, v 28, no. 2A, p 266-278. 
Damon, P E and Sonett, C P, 1989, Solar and terrestrial components of the atmospheric ${ }^{14} \mathrm{C}$ variation spectrum, in Sonett, C P, ed, The sun in time: Tucson, Univ Arizona Press (in press).

Damon, P E, Sternberg, R S and Radnell, C J, 1982, Modeling of atmospheric radiocarbon fluctuations for the past three centuries, in Stuiver, $\mathrm{M}$ and $\mathrm{Kra}$, R S, eds, Internatl ${ }^{14} \mathrm{C}$ conf, 11th, Proc: Radiocarbon, v 25, no. 2, p 249-258.

Hay, W H, 1985, Potential errors in estimates of carbonate rock accumulating through geologic time, in Sundquist, E T and Broecker, W S, eds, The carbon cycle and atmospheric $\mathrm{CO}_{2}$ : Natural variation Archean to Present: Am Geophys Union Mono 32, p 573-584.

Kemp, S, 1979, Carbon in the fresh water cycle, in Bolin, B, Degens, E T, Kemp, S and Ketner P, eds, The global carbon cycle, Scope 13: New York, John Wiley \& Sons, chapt 12, p 317342

Korff, S A and Mendell, R B, 1980, Variations in radiocarbon production in the earth's atmosphere, in Stuiver, $\mathrm{M}$ and Kra, R S, eds, Internat ${ }^{14} \mathrm{C}$ conf, 10th, Proc: Radiocarbon, $v 22$, no. 2, p 159-165.

Kromer, B, Rhein, M, Bruns, M, Schock-Fischer, H, Münnich, K O, Stuiver, M and Becker B, 1986, Radiocarbon calibration data for the 6th to 8th millennia BC, in Stuiver, $M$ and Kra, R S, eds, Internatl ${ }^{14} \mathrm{C}$ conf, 12th, Proc: Radiocarbon, v 28, no. 2B, p 954-960.

Light, E S, Merker, M, Verschell, H J, Mendill, R B and Korff, S A, 1973, Time-dependent world wide distribution of atmospheric neutrons and of their products, II, Calculation: Jour

Geophys Research, v 78, no. 16, p 2741-2762.

Lingenfelter, R E and Ramaty, R, 1970, Astrophysical and geophysical variations in C 14 production, in Olsson, I U, ed, Radiocarbon variations and absolute chronology, Nobel symposium, 12th, Proc: New York, John Wiley \& Sons, p 513-537.

McElhinny, M W and Senanyake, W E, 1982, Variations in the geomagnetic dipole 1: The past 50,000 years: Jour Geomag Geoelect, v 34, p 39-51.

Merker, M, 1971, Solar cycle modulation of fast neutrons in the atmosphere: PhD dissertation, New York Univ, Univ Microfilms, Ann Arbor, Michigan.

Mulholland, P J, 1981, Deposition of river borne organic carbon in floodplain wetlands and delta, in Flux of organic carbon by rivers to the oceans (CONF-8009140): US Dept Energy, Washington, DC (NTIS, Springfield, Virginia), p 142-172.

O'Brien, K J, 1979, Secular variations in the production of cosmogenic isotopes: Jour Geophys Research, v 84, p 423-431.

Oeschger, H, Siegenthaler, U, Gugelmann, A and Schotterer, U, 1975, A box diffusion model to study the carbon dioxide exchange in nature: Tellus, $v 27, \mathrm{p} 168-192$

Olson, J S, Garrels, R M, Berner, R A, Armentano, T V, Dyer, M I and Yaalon, D H, 1985 The natural carbon cycle, in Trabalka, J R, ed, Atmospheric carbon dioxide and the global carbon cycle: US Dept Energy Rept DOE/ER-0239, p 175-214.

Olsson, I U, ed, 1970, Radiocarbon variations and absolute chronology, Nobel symposium, 12th, Proc: New York, John Wiley \& Sons, $652 \mathrm{p}$

Povinec, P, 1977, Influence of the 11-yr solar cycle on the radiocarbon variations in the atmosphere: Acta Physica Comeniana, v 18, p 139-149.

Siegenthaler, $\mathrm{U}$, in press, ${ }^{14} \mathrm{C}$ in the oceans, in Fontes, $\mathrm{J}$ Ch and Fritz, $\mathrm{P}$, eds, Handbook of environmental isotope geochemistry, vol 3: Amsterdam, Elsevier.

Siegenthaler, U, Heimann, $\mathrm{M}$ and Oeschger, $\mathrm{H}, 1980,{ }^{14} \mathrm{C}$ variations caused by changes in the global carbon cycle, in Stuiver, $\mathrm{M}$ and $\mathrm{Kra}, \mathrm{R} \mathrm{S}$, eds, Internatl ${ }^{14} \mathrm{C}$ conf, 10 th, Proc: Radiocarbon, v 22, no. 2, p 177-191.

Sternberg, R S and Damon, P E, 1979, Sensitivity of radiocarbon fluctuations and inventory to geomagnetic parameters, in Berger, $\mathrm{R}$ and Suess, $\mathrm{HE}$, eds, Radiocarbon dating, Internatl ${ }^{\mathrm{P}} \mathrm{C}$ conf, 9th, Proc: Berkeley, Univ California Press, p 691-720.

Stuiver, M and Quay, P D, 1980, Changes in atmospheric carbon-14 attributed to a variable sun: Science, v 9, no. 4426, p 11-19.

Sundquist, E T, 1985, Geological perspectives on carbon dioxide and the carbon cycle, in Sundquist, E T and Broecker, W S, eds, The carbon cycle and atmospheric $\mathrm{CO}_{2}$ : Natural variation Archean to Present: Am Geophys Union Mono 32, p 5-59.

Walsh, J J, 1984, The role of the ocean biota in accelerated global ecological cycle: Atmospheric perspective: Bioscience, $v$ 34, p 499-507.

Wollast, P M and Billen, G, 1981, The fate of terrestrial organic carbon in the coastal area, in Flux of organic carbon by rivers to the oceans (CONF-8009140): US Dept Energy, Washington, DC (NTIS, Springfield, Virginia), p 331-359. 